\title{
MENUSANTARAKAN AL-QURAN: MENGEMBALIKAN KEGEMILANGAN BUDAYA KERUKUNAN ANTAR UMAT BERAGAMA
}

\author{
Lufaefi \\ Fakultas Ushuludin Sekolah Tinggi Filsafat Islam Sadra \\ Jl. Lebak Bulus 02 No. 2 Cilandak Barat. \\ Cilandak, Jakarta Selatan, 12440 \\ E-mail: eepivanosky@gmail.com
}

\begin{abstract}
Diversity is a fact that is often denied by some who do not want to be responsible, so often assume others who disagree and not the same as himself as the culprit of mistakes, and he is the most correct among others. They forget the history of the plurality of the country. This has actually hurt the already grounded culture in the archipelago that this nation was born into a culture of diversity. Unfortunately, the person who is reluctant to take responsibility often makes the verses of the Quran justify his behavior. Consequently, the Qur'an is often politicized for the benefit of the individual, or even his group by putting aside the cultural heritage mentioned above. Yet the essence of holy revelation [al-Quran] always tells us to uphold the truth in diversity culture. The culture of multiculturalism is indeed embodied and legalized in the Qur'an. This is in accordance with the mission of the Koran itself as a revelation that saalih likulli time wa al-meal that has long confirmed the legality of difference and diversity.
\end{abstract}

Keywords: al Qur'an, archiphelago, diversity, culture, plurality.

\begin{abstract}
ABSTRAK
Keberagaman merupakan fakta yang sering dinafikan oleh sebagian orang yang tidak mau bertanggung jawab, sehingga sering kali menganggap orang lain yang tidak sepaham dan tidak sama dengan dirinya sebagai biang kesalahan, dan dirinyalah yang paling benar diantara yang lain. Mereka melupakan sejarah kemajemukan negeri ini. Hal ini sejatinya telah mencederai budaya yang sudah membumi di nusantara bahwa bangsa ini terlahir atas budaya keberagaman. Sayangnya, orang yang enggan untuk bertanggung jawab tersebut sering menjadikan ayat Al-Quran sebagai justifikasi kelakuannya itu. Akibatnya al-Quran sering dipolitisasi demi kepentingan pribadi, atau bahkan kelompoknya dengan mengesampingkan warisan budaya tersebut di atas. Padahal hakikatnya wahyu suci [al-Quran] selalu menyuruh kita untuk menegakkan kebenaran dalam budaya keberagaman. Budaya multikulturalisme sungguh termaktub dan dilegalkan di dalam al-Quran. Hal ini sesuai
\end{abstract}


dengan misi al-Quran itu sendiri sebagai wahyu yang saalih likulli zaman wa al-makan yang telah sejak lama mengkonfirmasi akan legalitas perbedaan dan keberagaman.

Kata Kunci: al Qur an, Nusantara, keberagaman, budaya, pluralitas.

\section{PENDAHULUAN}

Ciri yang paling indah bagi bangsa Indonesia adalah budaya pluralitasnya dari berbagai aspek, baik ras, suku, adat, bahasa dan agama. Dari aspek agama, Indonesia memiliki enam agama yang sah, yaitu Islam, Protestan, Kristen, Hindu, Buddha dan Konghucu. Namun, tidak jarang keberagaman ini menimbulkan konflik antar satu umat beragama dengan yang lain ${ }^{1}$. Praktek intoleransi banyak ditemukan di berbagai sudut nusantara ini. Padahal, keberagaman ini sudah menjadi watak banga Indonesia. Bahkan, berdirinya banga ini juga atas dasar keberagaman yang ada di dalamnya ${ }^{2}$. Sungguh sejatinya Indonesia sudah mendarah daging perihal hidup dalam keberagaman.

Maraknya tindakan intoleransi antar kelompok agama disebabkan oleh pemahaman umat beragama terhadap teks-teks agama, terutama pemahaman terhadap ayat-ayat al-Quran sebagai sumber utama kaum muslim. ${ }^{3}$ Hal ini rasional, sebab al-Quran merupakan sumber utama umat Islam. Maka bukan hal yang aneh jika isu-isu intoleransi sering dipredikatkan kepada orangorang yang memeluk agama Islam. Islam sering sekali dituding sebagai agama kekerasan, teror, dan agama biang keganasan terhadap yang tidak sepaham ${ }^{4}$. Sebagai contoh misalnya, kekerasan terhadap warga Muslim Rohingnya di Myanmar tiba-tiba memicu ketegangan terhadap umat Buddha di Indonesia, munculnya ancaman penutupan klenteng umat Buddha di berbagai tempat, termasuk penyerangan terhadap dua kelenteng Buddhis di Makassar, Sulawasi Selatan ${ }^{5}$. Padahal sebelum peristiwa di Rohingnya tidak ada konflik yang dirasakan terhadap pemeluk agama Buddha oleh kaum Muslim di Indonesia.

Menjadi hal yang tidak diharapkan adalah bahwa, konflik berdasarkan agama dapat meluas seperti kasus konflik di Poso dan Ambon, dimana pelaku konflik banyak mendatangkan

\footnotetext{
${ }^{1}$ Hamka Haq, Kandungan Nilai-Nilai Islam dalam Pancasila, jurnal Millah Vol. XIII, No. 1, Agustus 2013, hal. 206

${ }^{2}$ Abdul Musi Naharong, Teologi Kekerasan: Pandangan Jihad Abdul Salam Faraj dan Imam Samudra, jurnal Falsafah dan Agama, vol. 1, No. 1, April 2007, hal. 335

${ }^{3}$ Makmun Rasyid, HTI Gagal Paham Khilafah, (Ciputat: Pustaka Compass, 2016), hal. 19

${ }^{4}$ Nurdin Zuhdi, HERMENEUTIKA AL-QUR'AN: Tipologi Tafsir Sebagai Solusi dalam Memecahkan Isu-Isu Budaya Lokal Keindonesiaan, jurnal ESENSIA Vol. XIII No. 2 Juli 2012,

${ }^{5}$ Didah, Indeks Kerukunan Umat Beragama 2016 Naik, http://www.kemenag.go.id/berita/47039, diakses pada 02 Juni 2017, pkl. 16.27 wib.
} 
pihak dari luar daerah, baik dari Kristen ataupun Muslim itu sendiri ${ }^{6}$. Semua itu bertentangan dengan budaya bangsa yang telah lama mencerminkan budaya keberagaman. Semboyan Bhinneka Tunggal Ika ialah sebagai bukti akan sangat pluralitasnya negara Indonesia dalam banyak aspeknya.

Menurut Komnas HAM, pada tahun 2010-2013 saja pengaduan tentang peristiwa pelanggaran kebebasan dan keberagaman beragama serta keyakinan begitu tinggi. Pada tahun 2010 sendiri Komnas HAM menerima 84 buah pengaduan, yang terdiri dari kasus perusakan, gangguan dan penyegelan rumah ibadah sebanyak 26 kasus, dengan perincian kekerasan terhadap aliran yang diklaim sesat sebanyak 14 kasus, konflik dan sengketa internal 7 kasus, dan 6 kasus pelanggaran terhadap pelarangan Ahmadiyah, serta pelanggaran-pelanggaran lainnya. Pada tahun 2011, pengaduan yang masuk sebanyak 83 kasus, dengan 32 kasus terkait pelanggaran atas perusakan tempat ibadah, 21 kasus terkait Ahmadiyah, gangguan dan pelanggaran ibadah sebanyak 13 kasus, dan diskriminasi atas minoritas agama sebanyak 6 kasus. Sedangkan pada tahun 2012, tercatat 68 pengaduan kepada Komnas HAM, dengan perincian sebanyak 20 kasus perusakan dan penyegelan rumah ibadah, konflik dan sengketa internal 19 kasus, gangguan ibadah 17 kasus, dan diskriminasi minoritas 6 kasus. Kemudian pada tahun 2013 Komnas HAM menerima 39 berkas pengaduan, 21 kasus berupa diskriminasi, pengancaman dan kekerasan terhadap pemeluk agama, penghalangan pendirian rumah ibadah sebanyak 9 kasus dan penghalangan terhadap ritual pelaksanaan agama sebanyak 9 berkas ${ }^{7}$.

Data di atas adalah bukti akan hampir hilangnya budaya kerukunan umat beragama di negeri ini. Saling merasa paling benar dan menyalahkan keyakinan orang lain hampir menjamur di negeri ini. Padahal negeri ini terbangun atas keberagaman yang tak bisa dinafikan. Kegemilangan atas keberagaman yang melahirkan kerukunan antar umat beragama hampir saja menjadi luntur dan punah.

Maraknya intoleransi dan tidak menghormati antar sesama anak bangsa disebabkan karena pemahaman agama beberapa kelompok terhadap teks wahyu ${ }^{8}$. Sumber hukum utama, dalam hal ini al-Quran, menjadi dalil untuk mencuatkan isu-isu yang sungguh menggerogoti budaya banga Indonesia dalam kerukunannya. Semua itu tidak lain sebab pemahaman terhadap teks al-Quran yang terlalu sempit dan lepas dari hakikat ayat al-Quran sebagai wahyu yang

\footnotetext{
${ }^{6}$ Abdul Musi Naharong, Teologi Kekerasan: Pandangan Jihad Abdul Salam Faraj dan Imam Samudra, hal. 33

${ }^{7}$ Abdul Musi Naharong, Teologi Kekerasan: Pandangan Jihad Abdul Salam Faraj dan Imam Samudra, , hal. 335

${ }^{8}$ Makmun Rasyid, HTI Gagal Paham Khilafah, hal. 19
} 
semeskinya mampu menjadi petunjuk dan menyejukkan ${ }^{9}$ Padahal jika kita bertanya, masuk akalkah al-Quran sebagai petunjuk manusia mengajarkan manusia itu sendiri untuk berpecah belah? Betapa ini bertentangan dengan ayat al-Quran QS. Ali Imran: 103.

Tulisan ini akan mencoba me-reinterpretasi dan mengkontekstualisasikan [di nusantara] ayat-ayat al-Quran yang sering dijadikan legitimasi kelompok-kelompok beragama dalam usaha melegalkan kekerasan terhadap kelompok lain yang berbeda. Melalui pendekatan hermeneutika Fazlur Rohman ${ }^{10}$ dan analisis semiotika ayat-ayat tersebut nantinya, tulisan ini akan mencoba memberikan bentuk penafsiran yang komprehensif, sehingga menempatkan al-Quran sebagaimana meskinya, yakni menjadi perwujudan wahyu yang mampu menjadi punggung keberagaman, khususnya di indonesia sebagai negeri multikultural. Dengan ini diharapkan ayatayat al-Quran akan mengembalaikan kegemilangan yang pernah ditorehkan banga Indonesia dengan latar keberagamannya dan kerukunan antarumat beragama di dalamnya.

\section{Potret Kerukunan Umat Beragama di Indonesia}

Kerukunan umat beragama merupakan dambaan setiap umat manusia. Sebagian besar umat beragama di dunia ingin hidup rukun, damai dan tentram dalam menjalankan kehidupan bermasyarakat dan bernegara serta dalam menjalankan ibadahnya. Hal ini sangat selaras dengan keiscayaan atas hadits nabi bahwa manusia pada kodratnya menghendaki ketentraman ${ }^{11}$.

Bangsa Indonesia diciptakan dan ditakdirkan oleh Tuhan dalam suasana kemajemukan, baik itu suku, ras, agama maupun budaya. Indonesia sebagai negara kepulauan terbesar di dunia dengan beragamnya sosial-budaya akan tetap menjadi gejala yang diperhitungkan dalam mewujudkan masyarakat yang tentram dan damai. Kemajemukan dan kerukunan antar umat beragam merupakan budaya yang Tuhan ciptakan bagi bangsa yang beragam tersebut. Semua itu merupakan kenyataan hidup yang semesinya tak boleh diganggu gugat dengan mencemarkan virus-virus intoleransi di tubuh bangsa Indonesia.

Pada pasal 29 ayat 2 UUD 1945 menyatakan bahwa negara menjamin kemerdekaan tiaptiap penduduk untuk memeluk agamanya masing-masing dan untuk beribadat menurut agama

\footnotetext{
${ }^{9}$ Idrus Ruslan, Membangun Harmonisasi Kehidupan Berbangsa dan Bernegara dengan Nilai Islam pada Pancasila, Jurnal TAPIs: IAIN Raden Intan Lampung, Vol. 9, No. 2, 2003, hal. 5

10 Teori Fazlur Rohman yaitu teori hermeneutika double movement, di mana ayat al-Quran dikembalikan maknanya ke zaman awal turunnya, kemudian dikembalikan lagi pada masa sekarang. Lihat Hasan Qosim, Pemikiran Fazlur Rohman, hqoshim.blosspot.co.id/2014/12/ pemikiran-falur-rohman.html?m, diakses pada 02 Juni 2017, pkl. 22.09 wib

${ }^{11}$ Lihat hadits ke 494 hadits Imam Ahmad, disebutkan bahwa Nabi Muhammad SAW meniscayakan ketentraman dan ketenangan terhadap umatnya.
} 
dan kepercayaannya itu ${ }^{12}$. Selama berabad-abad, suku bangsa di Indonesia umumnya hidup rukun tanpa benturan yang berarti. Falsafah Pancasila yang bertumpu pada Ketuhanan Yang Maha Esa memberi konsep kerukunan dan perdamaian abadi bagi bangsa Indonesia ${ }^{13}$.

Budaya kerukunan dan keberagaman agama sudah seharusnya dibina dan dijaga demi terciptanya bangsa dan negara yang didambakan oleh setiap warganya. Potret bahwa Indonesia pada dasarnya memiliki watak menghormati keberagaman adalah tidak bisa dinafikan. Setiap kita harus menjaga dan merangkul keberagaman yang sudah semeskinya abadai bagi bangsa yang diperjuangkan melalui keberagaman tersebut.

\section{Al-Quran dan Budaya Kerukunan}

Mereka yang tak ingin bertanggung jawab selalu menginginkan agar Negara bangsa ini memiliki satu keyakinan. Mereka tidak menginginkan bilamana orang selain diri mereka memahami keyakinan sebagaimana yang diyakininnya. Padahal kita sadar bahwa keyakinan adalah masalah privasi seorang hamba dengan Tuhannya ${ }^{14}$. Heterogenitas bangsa sejatinya sudah menjadi budaya yang melekat dalam sanubari setiap pendudukanya. Keberagaman merupakan hal yang paling membedakan bangsa Indonesia dengan bangsa-bangsa lainnya. Semuanya itu sudah mengakar sejak lama dan siapa saja mengakuinya ${ }^{15}$. Oleh sebab itu meskinya keberagaman tidak perlu untuk diperdebatkan dan dipermasalahkan.

Keinginan kaum yang tidak bertanggung jawab tersebut selalu menjustifikasi keberagaman sebagai sesuatu yang akan membuat perpecahan, berbeda pemahaman dan saling salah menyalahkan ${ }^{16}$. Sehingga semua itu harus disatukan satu keyakinan. Mereka mengklaim bahwa bukan karena perbedaan yang membuat pertikaian, tetapi sejatinya tidak sama seperti yang mereka pahami adalah yang menjadi masalah. Sehingga pun mereka kekeuh bahwa di AlQuran tidak melegalkan keberagaman dan keheterogenan ${ }^{17}$. Atas hal itu lah perlunya kita menilik dan menginterpretasi ulang serta menusantarakan penafsiran ayat-ayat yang dijadikan justifikasi atas kekerasan dan ketidakberagaman. Sudah semeskinya kita menunjukkan kembali

\footnotetext{
${ }^{12}$ Lihat UUD 1945 Pasal 29 Ayat 2

${ }^{13}$ Saifullah Rohman, Kandungan Nilai-nilai Islam dalam Pancasila, Jurnal Millah: Pusat Penelitian Kemasyarakatan dan Kebudayaan (PMB-LIPI), Vol. xiii, No. 1, 2013, hal. 208

14 Aulia Kushardini, Kalau Agama Itu Urusan Manusia dan Tuhannya, Kenap Tanya Dia Gak Puasa, www.hipwee.com/feature/kalau-agama-itu-urusan-manusia-dan-tuhannya-kenapa-tanya-dia-gak-puasa/, diakss pada 02 Juni 2017, pkl. 16.42 wib

${ }^{15}$ Husein Muhammad, Mengaji Pluralisme, (Bandung: Mizan, 2011), hal. 4

${ }^{16}$ Nurdin Zuhdi, HERMENEUTIKA AL-QUR'AN: Tipologi Tafsir Sebagai Solusi dalam Memecahkan Isu-Isu Budaya Lokal Keindonesiaan, 245

${ }^{17}$ Agus Salim Fattah, Pesantren Membangun Bangsa, (Tangerang: Compass, 2009), hal. 84
} 
makna al-Quran yang sejati yang meskinya menentramkan dan mendamaikan. Berikut beberapa ayat tersebut: Qs. Al-Hajj ayat 39-40

"Diizinkan (berperang) bagi orang-orang yang diperangi, karena sesungguhnya mereka didzalimi. Dan sungguh Allah Maha Kuasa Menolong mereka itu, yaitu orang-orang yang diusir dari kampung halamannya tanpa alasan yang benar, hanya karena mereka berkata, “Tuhan kami ialah Allah”. Seandainya Allah tidak menolak (keganasan) sebagian manusia dengan sebagian yang lain, tentu telah dirobohkan biara-biara nasrani, gereja-gereja, rumahrumah ibadah orang Yahudi dan masjid-masjid, yang di dalamnya banyak disebut nama Allah. Allah pasti akan menolong orang yang menolong (agama)-Nya. Sungguh, Allah Mahakuat, Mahaperkasa." Ayat ini adalah salah satu ayat yang sering dijadikan legitimasi dalil kelompokkelompok ekstrem dalam usaha membolehkan aksi kekerasannya atas nama jihad dalam memerangi siapa saja yang berbeda keyakinan serta menafikan kebaragaman ${ }^{18}$. Mereka tidak pernah merasa bahwa aksinya tersebut bertentangan dengan Islam ${ }^{19}$. Sebab meraka merasa telah dilegalkan aksi kekerasannya tersebut oleh al-Quran yang dipahaminya. Mereka menafsikan budaya keragaman yang ada dalam al-Quran.

Ayat di atas memang merupakan sebuah izin dari Allah untuk melakukan peperangan terhadap kaum musyrikin saat itu. Akan tetapi bukan berarti ayat ini kemudian dijadikan dalil kekerasan begitu saja ketika melihat "perbedaan" melekat pada diri orang lain. Karena jika dilihat dari asbabunnuzulnya Rasulullah dan kaum muslimin saat itu mendapatkan perlakuan kasar dan ditindas (secara fisik) oleh kaum musyrikin Makkah dalam waktu yang sudah cukup lama, sementara kaum Muslimin belum bisa melakukan apapun sebelum turunnya ayat ini ${ }^{20}$.

Dalam tafsiran Ibn Katsir mengenai penafsiran ayat di atas, dijelaskan bahwa Al-Aufi berkata kepada Ibn Abbas, pada awalnya Nabi Muhammad SAW dan para sahabatnya dikeluarkan atau diusir dari Mekkah tanpa alasan yang benar, sehingga kemudian munculnya perlawanan dari kaum Muslimin ${ }^{21}$. Hal tersebut juga dikuatkan oleh sebuah hadits dari Imam Ahmad, dimana beliau menilai hadits ini sebagai hadits hasan oleh Turmudzi dan dinilai shahih oleh Imam Hakim, bahwa melalui sahabat Ibn Abbas ra, Nabi SAW keluar dari Mekkah dan sahabat Abu Bakar mengatakan "mereka (orang-orang Quraiys) telah mengusir nabi mereka

\footnotetext{
${ }^{18}$ A. Khoir, Awas! Buku Radikal Pelintir Ayat Al-Quran, NU Online/com/new/, diakses pada Selasa, 11 April 2017, pkl. 09.29 wib

${ }^{19}$ A. Khoir, Awas! Buku Radikal Pelintir Ayat Al-Quran, NU Online/com/new/, diakses pada Selasa, 11 April 2017, pkl. 09.38 wib

${ }^{20}$ M Quraish Shihab, Tafsir Al-Misbah, (Jakarta: Lentera Hati, 2002), hal.65

${ }^{21}$ Abdullah Bin Muhamad Bin Abdurrahman Bin Ishaq Alu Syaikh, Tafsir Ibn Katsir, (Jakarta: Pustaka Imam Syafi'i, 2011) Jilid enam, hal 175.
} 
yang akibatnya mereka akan binasa, kemudian Allah SWT menurunkan firman ini"22. Yang perlu digarisbawahi bahwa Nabi dan kaum Muslim tidak memulai peperangan tanpa sebab apapun.

Kalimat "telah diizinkan" ini berarti bahwa ada usaha sebelumnya dari kaum Muslim saat itu untuk membela agama Allah dengan cara lain selain melakukan peperangan ${ }^{23}$. Hal ini menunjukan betapa Islam sebagai rahmat lil 'alamin menghendaki sebuah cara yang damai dan menghormati keberagaman. Tidak diwajibkan membuat rugi dengan kekerasan, terlebih jika tidak adanya penganiayaan fisik oleh mereka ${ }^{24}$. Selain itu, ayat ini juga secara tersirat mengungkapkan kepada pembaca bahwa bukan kaum muslimlah yang pertama kali memicu terjadinya peperangan melainkan orang musyrik itu sendiri ${ }^{25}$. Sehingga ketika keadaan yang mendesak, barulah kaum muslim boleh memerangi. Pada akhirnya, ayat ini memberi legalitas akan perbedaan, di mana kaum muslimin sebelum diperangi mereka diam dan sekadar dakwah untuk masuk Islam, bukan memaksa.

Jika memang Islam menghendaki perdamaian, mungkin kita akan bertanya, kenapa perang kemudian disyariatkan? perang disyariatkan Allah untuk mereka (muslim) karena Allah ingin menguji kaum muslimin dan mengangkat mereka sebagai syuhada ${ }^{26}$. Sementara itu, dalam tafsiran Ibn Katsir ditegaskan, bahwa syariat untuk berperang, Tuhan perintahkan kepada manusia agar mereka mengerahkan kemampuannya semaksimal mungkin dalam ketaatan kepada-Nya, bukan memulai memerangi dahulu, seperti yang tercatat dalam surat Muhammad [47]: 04 yang artinya:“Apabila kamu bertemu dengan orang-orang kafir (di medan perang) maka pancunglah batang leher mereka. Sehingga apabila kamu telah mengalahkan mereka maka tawanlah mereka dan sesudah itu kamu boleh membebaskan mereka atau menerima tebusan sampai perang berakhir. Demikianlah apabila Allah menghendaki niscaya Allah akan membinasakan mereka tetapi Allah hendak menguji sebahagian kamu dengan sebahagian yang lain. Dan orang-orang yang syahid pada jalan Allah, Allah tidak akan menyia-nyiakan amal mereka".

Maka jelaslah interpretasi bahwa ayat di atas sebagai dalil dibolehkan dan diwajibkan untuk berperang dan memerangi siapa saja yang berbeda merupakan hal yang terlalu terburu-

\footnotetext{
22 Imam jalaludin Al-Mahali dan Imam jalaludin Asuyuthi , Tafsir Jalalain, (Bandung, PT Sinar Baru Al-Gensindo,

${ }^{23}$ Al-Baidhawi, Anwar At-Tanzil dan Wa Asrar At'takwil, (Beirut: Daar Ihya Al-Turats Al-Arabi, 1438), jilid 4, hal. 74

${ }^{24}$ Abdul Malik Utsman, Ismah Rahmah dan Wasathiyah, jurnal Humanika Vol. 15 Nomor 1. September 2015, hal. 6

${ }^{25}$ Muhammad Ali Al-Shobuni, Shafwa Al-Tafasir Tafsir AL-Quran Al-Karim, (Beirut: Daar Al-Fikr, 1421), juz 2, hal. 267

${ }^{26}$ M Quraish Shihab, Tafsir Al-Misbah, hal 65
} 
buru. Telah jelas juga bahwa Nabi melakukan peperangan karena diawali perang dan disakiti oleh kaum musyrik dan diperangi secara fisik ${ }^{27}$, bukan yang lain.

Jika kita kontekstualisasikan dalam keindonesiaan, yang mana dengan perbedaan dan keberagaman yang ada sejatinya bisa rukun, sebab tiadanya penyerangan fisik apapun antar satu kelompok dengan yang lain, sangat salah untuk mengatakan bahwa ayat di atas sebagai dalil untuk memperlakukan kekerasan kepada orang atau kelompok yang berbeda keyakinan ${ }^{28}$. Perlu ditegaskan lagi, tiadanya penyerangan fisik dan tidak dimulainya peperangan dari Nabi dan kaum Muslaim memberi kesimpulan bahwa aksi peperangan atau kekerasan dibolehkan manakala ada segolongan yang memerangi kita terlebih dahulu secara fisik. Jika tidak, maka tidak sedikitpun boleh untuk memerangi terlebih dahulu atau melakukan aksi kekerasan. Justru meskinya kita menebar kedamaian dan perdamaian dalam perbedaan dan keberagaman di dalamnya, karena itulah prinsip al-Quran sebagai petunjuk dan penyejuk. Hal ini bisa dibuktikan pada ayat al-Quran surat Ar-Rum ayat 22: Dan di antara tanda-tanda kekuasaan-Nya ialah menciptakan langit dan bumi dan berlain-lainan bahasamu dan warna kulitmu. Sesungguhnya pada yang demikian itu benar-benar terdapat tanda-tanda bagi orang-orang yang mengetahui.

Dalam ayat di atas sangat jelas bahwa perbedaan yang ada di muka bumi ini merupakan tanda bagi kekuasaan Allah swt. Kita tidak bisa menafikan bahwa ayat di atas melegalkan akan budaya perbedaan dan menuntut untuk terwujudnya kerukunan umat beragama ayang berbeda dalam setiap waktunya. Maka siapa saja yang mencoba merubah budaya perbedaan yang telah melahirkan kerukanan dalam umat, ia adalah tidak terima dengan keagungan Allah swt.

Baidhawi dalam tafsirnya merincikan maksud berbeda lisan-lisannya ialah berbeda dalam bahasa pengucapan, lughat, gaya bahasa, jenisnya, kadar kiranya dan sebagainya. Dan berbeda warna kulitmu dengan berbagai macam ${ }^{29}$. Semua itu merupakan tanda bagi kekuasaan Alah swt. Tidak boleh ditolak dan dikesampingkan. Kita bukan berbeda dalam satu, tetapi kita semua hanya berbeda dalam memahami yang satu.

\footnotetext{
27 Jalaluddin Al-Suyuthi, Al-Dura Al-Mansur, (Qum: Maktabah Al-Mar'asyi An-Najafi, 1400), jilid 4, hal. 364, AlAlushi, Ruh Al-Ma'ani fi Tafsir Al-Quran wa Al-Sab'u Al-Matsani, (Beirut: Daar Al-Kutub Al-Islami, 1415), jilid 9, hal. 154, dan Haki Al-Barushi, Tafsir Ruh Al-Bayan, (Beirut: Daar Al-Fikr, 1440), jilid 4, hal. 38.

${ }^{28}$ Sebagaimana misi Al-Quran "salih likuli zaman wa al-makan", maka sudah semeskinya ayat al-Quran menjadi pedoman seluruh umat Islam, apapun keyakinannya, keagamaannya, dan sukunya, semuanya harus merasakan kenyamanan dan kedamaian dari wahyu tersebut, lihat: Nurdin Zuhdi, Hermeneutika Al-Qur'an: Tipologi Tafsir Sebagai Solusi dalam Memecahkan Isu-Isu Budaya Lokal Keindonesiaan, hal. 258

${ }^{29}$ Al-Baidhawi, Anwar At-Tanzil dan Wa Asrar At'takwil, (Beirut: Daar Ihya Al-Turats Al-Arabi, 2014 ), jilid 4, no. 1438.
} 
Ayat lain yang sering dijadikan sebagai legitimasi memerangi dan tidak menghormati keberagaman dan perbedaan adalah QS.At-Taubah [9]: 5: “Apabila sudah habis bulan-bulan Haram itu, maka bunuhlah orang-orang musyrikin itu dimana saja kamu jumpai mereka, dan tangkaplah mereka. Kepunglah mereka dan intailah ditempat pengintaian. Jika mereka bertaubat dan mendirikan sholat dan menunaikan zakat, maka berilah kebebasan kepada mereka untuk berjalan. Sesungguhnya Allah Maha Pengampun lagi Maha Penyayang”.

Diketahui bersama bahwa pengucapan basmalah tidak dianjurkan ketika akan membaca surat At-Taubah. Berdasarkan tafsir Jalalain, jika dilihat dari asbabunnuzulnya surat, hal ini dikarenakan surat At-Taubah merupakan surat "azab" dan salah satu perintah yang ada dalam surat ini adalah penggunaan pedang (berperang) ${ }^{30}$. Artinya bahwa ayat-ayat dalam surat atTaubah ini sangat jelas berimplikasi dijadikan dalil dalam peperangan dan atau kekerasan terhadap mereka yang berbeda keyakinan dan tidaknya menghormati budaya keberagaman.

Surah ini turun sekitar lima belas bulan sebelum nabi wafat, atau dengan kata lain, surah ini turun sekitar 22 tahun setelah turunnya ayat pertama. Ini menunjukan bahwa Islam selalu mengajak pada perdamaian dan menciptakan suasana aman bagi siapapun tak terkecuali orang Musyrik. Islam sangat mengedepankan nilai-nilai perbedaan. Adapun peperangan yang dilakukan nabi ketika di Madinah, mengutip dari tafsiran Qurays Shihab, Muhammad AlGazhali menyebutkan bahwa selama 22 tahun Rasulullah melakukan perang, hanya sekitar 200 orang yang meninggal dari kalangan musyrikin ${ }^{31}$.

Dari uraian di atas dapat kita ambil sebuah poin, bahwa pada hakikatnya Islam selalu menawarkan jalan yang damai tanpa harus menumpahkan darah sesama manusia. Adapun perang yang kemudian dilakukan kaum muslim itu merupakan perlawanan untuk mempertahankan diri ${ }^{32}$. Rasulullah dan kaum muslim tidak sama sekali memulai memerangi kaum musyrik atau kafir. Betapa Rasulullah sangat menghargai dan mengedepankan perbedaan dan keberagaman.

Kembali pada penafsiran ayat di atas, bahwa bulan-bulan haram yang dimaksud dalam ayat tersebut adalah Dzul'qaidah, Dzul Hijjah, Muaharram, dan Rajab. Ayat itu menjelaskan apabila keempat bulan itu sudah selesai/berlalu, maka bunuhlah orang-orang musyrik dimana saja dan kapan saja. Hal ini dimaksudkan kepada orang-orang musyrik yang selama ini telah

\footnotetext{
${ }^{30}$ Imam Jalaludin Al-Mahali dan Imam Jalaludin Asuyuthi , Tafsir jalalain, (Bandung, PT Sinar Baru Al-Gensindo), diterjemahkan oleh Bahrun Abu Bakar, hal 717

${ }^{31}$ M Quraish Shihab, Tafsir Al-Misbah, hal 527

${ }^{32}$ Al-Alushi, Ruh Al-Ma'ani fi Tafsir Al-Quran wa Al-Sab’u Al-Matsani, jilid 9, hal. 154
} 
menghalangi kaum muslim untuk beribadah ${ }^{33}$. Kaum muslimin tidak sama sekali mendahului perang terhadap keyaninan yang berbeda. Jika perbedaan agama saja dibedakan, sudah semeskinya Rasulullah menghormati keberagaman-keberagaman yang lain.

Dengan demikian dapat dikatakan bahwa perintah untuk membunuh terhadap mereka yang berbeda keyakinan di sini bukanlah sesuatu yang diwajibkan melainkan hanya sekadar alternatif untuk melawan para kaum musyrikin ${ }^{34}$. Adapun perlawanan yang muslim lakukan tentunya sesuai dengan perlakuan para kaum musyrik terhadap kaum muslim itu sendiri. Maka dari itu, tidak semua kaum musyrik memerangi kaum muslim, sehingga kaum musyrik yang memiliki kecenderungan untuk beriman kepada agama Islam dan tidak memerangi muslim, kita tidak diperbolehkan untuk memeranginya terlebih dahulu terhadap siapapun yang berbeda. Hal ini ditegaskan dalam kaliamat terakhir pada ayat di atas "Jika mereka bertaubat dan melaksanakan shalat, dan menunaikan zakat, maka lepaskanlah jalan mereka sesungguhnya Allah maha pengampun lagi Maha Penyayang”.

Shalat adalah berhubungan dengan Tuhan (Hablumminallah), sementara zakat menandakan bahwa kita juga harus memiliki hubungan yang baik dengan hamba-hamba-Nya (Hablumminannas). Adapun kalimat terakhir dalam surat ini Quraisy Shihab mengutip pernyataannya Thabathaba'i dimana seorang hamba sudah seharusnya meneladani sifat Allah yang Maha Pengampun lagi Maha Penyayang. dalam arti bahwa manusia, apapun keyakinannya meski saling menyayangi dan mengasihi satu sama lain, harus selalu damai, sebab ada hak hubungan dengan manusia.

Sementara itu Ibn Katsir menjawab persoalan ayat ini dengan menyatakan bahwa ayat tersebut dibatasi QS. Al-Baqarah [2]:191 yang artinya: Dan bunuhlah mereka di mana saja kamu jumpai mereka, dan usirlah mereka dari tempat mereka telah mengusir kamu (Makkah); dan fitnah itu lebih besar bahayanya dari pembunuhan, dan janganlah kamu memerangi mereka di Masjidil Haram, kecuali jika mereka memerangi kamu di tempat itu. Jika mereka memerangi kamu(di tempat itu), maka bunuhlah mereka. Demikanlah balasan bagi orang-orang kafir ${ }^{35}$.

Sebagaimana penjelasan dari atas, sisi historisitas ayat ini sangat jauh untuk dijadikan legitimasi kekerasan kepada mereka yang berbeda keyakinan, terlebih jika di Indonesia. AlQuran sebagai hudan sudah semeskinya bisa mengharmoniskan antar manusia dengan

\footnotetext{
${ }^{33}$ Ni'matullah Ibn Mahmud, Fawatih Al-Ilahiah wa Al-Mafatih Al-Ghaibiah, (Mesir: Daar Rukaab Li An-Nasyr, 1419), Jilid 1, hal. 298

${ }^{34}$ Quraish Shihab, Tafsir Al-Misbah, hal. 533

${ }^{35}$ Ibnu Katsir, Tafsir Al-Quran Al-'Azhim, (Beirut: Daar Al-Kitab Al-Islami, 1419), Jilid 4, hal. 98
} 
perbedaannya. Al-Quran harus menusantara ketika didudukkan di nusantara. Al-Quran meski menjadi penawar kedamaian di antara perbedaan, tak terkecuali di Indonesia ${ }^{36}$, termasuk maksud ayat di atas jika kita tarik melalui asbab an-nuzulnya, yaitu bukan sama sekali melegalkan peperangan dan menafikan keberagaman tanpa sabab mempertahankan diri dan tanpa diperangi terlebih dahulu. Betapa al-Quran sangat mengapresiasi keberagaman, Allah swt berfirman dalam QS. Al-Hujurat ayat 13: Hai manusia, sesungguhnya Kami menciptakan kamu dari seorang laki-laki dan seorang perempuan dan menjadikan kamu berbangsa - bangsa dan bersuku-suku supaya kamu saling kenal-mengenal. Sesungguhnya orang yang paling mulia diantara kamu disisi Allah ialah orang yang paling taqwa diantara kamu. Sesungguhnya Allah Maha Mengetahui lagi Maha Mengenal.

Dalam tafsir Ruhul Maani bahwa semua bahasa manusia terdiri dari 72 bahas. Dari banyaknya bahasa tersebut semeskinya manusia bisa saling mengharagai ${ }^{37}$. Sementara itu Ibn Athiyah dalam tafsir Muharrar al wajiz, memberi penafsiran bahwa maksud berbeda-beda warna ialah warna sebagaimana di dunia, atau bahwa anak Adam dengan berbagai cirinya ${ }^{38}$. Semua itu dikatakan sebagai nikmat Allah swt. Allah swt berfirman dalam QS. Yunus 19: Manusia dahulunya hanyalah satu umat kemudian mereka berselisih. Kalau tidaklah karena suatu ketetapan yang telah ada dari Tuhanmu dahulu, pastilah telah diberi keputusan di antara mereka, tentang apa yang mereka perselisihkan itu.

Manusia pada mulanya, yaitu sebelum diutusnya Nabi Nuh, berkeyakinan satu. Namun setelah itu, yakni setelah diutusnya Nabi Muhammad, manusia berbeda-beda dikarenakan ada yang taat pada Rasul dan ada yang mengingkari ${ }^{39}$. Ini memberi penegasan bahwa umat Muhammad akan selalu ada perbedaan di dalamnya. Sementara Mufassir lain mengatakan bahwa mansuai pada mulanya satu (satu keyakinan terhadap agama) sejak zaman Nabi Adam as, tetapi setelah peristiwa Qabil dan Habil kemudian manusia terjadi perpeahan setelahnya. ${ }^{40}$

Ayat di atas tidak memberi indikasi sebagai perintah untuk melakukan perpecahan dan atau menuruti hawa nafsu, tetapi sebagai kesadaran bahwa sejatinya perbedaan merupakan fitrah manusia yang tidak bisa digangu-gugat ${ }^{41}$.

\footnotetext{
${ }^{36}$ Zainudin, DAKWAH RAHMATAN LIL-'ALAMIN: Kajian tentang Toleransi Beragama dalam Surat al-Kafirun, hal 24

${ }^{37}$ Al-Baidhawi, Anwar At-Tanzil dan Wa Asrar At'takwil., Jilid 2, 32

${ }^{38}$ Ibn Athiyah, Muharrar Al-Wajiz, (Beirut: Dar Al-kutb Al-Islamy, 1422), jilid 4, hal 333

39

40 Muhammad, Kanzul Al-Daqa'iq wa Bahru Al-Ghara'ib, (Tehran:Muassasah Athab'ah wa Al-Nasyr, 1409), jilid 4, hal. 40

${ }^{41}$ Husain Fadhlullah, Tafsir Min Wahyi Al-Quran, (Beirut: Daar Al-Malaak, 1419), jilid 4, hal 84
} 


\section{Mengembalikan Kegemilangan Budaya Kerukunan Antar Umat Beragama}

Budaya keberagaman dan menghormati perbedaan sudah melekat dari dahulu dalam sanubari masyarakat Indonesia. Kerukunan antar umat beragama sudah menjadi potret yang indah bagi bangsa Indonesia sebagai negeri multikulturalisme. Kesadaran hal itu kemudian menjadi meluntur karena banyaknya anak bangsa yang enggan untuk sadar akan hakikat budaya yang semeskinya dijunjung tinggi oleh setiap insan Indonesia dan telah dilegalkan dalam ayat alQuran. Oleh sebab itu setiap kita memiliki tanggung jawab untuk mengembalikan budaya tersebut. Setiap manusia yang menempati bumi nusantara bertanggung jawab memikul tanggug jawab mengembalikan jati diri bangsa sebagai bangsa yang berbudaya dalam menghormati keberagaman dan perbedaan, terutamanya keberagaman beragama.

Menurut Habib (2011:01) cara efektif untuk mengembalikan budaya yang sudah terbangun di pundak bangsa Indonesia adalah dengan memulai dari diri sendiri, lebih jauh dia mengatakan, untuk membangun dan mengembalikan jati diri bangsa Indonesia yang rukun akan keberagaman, setiap insan Indonesia harus kembali menyadari akan pentinnga pancasila ${ }^{42}$. Hal ini sangat selaras sebab nilai-nilai Pancasila sungguhpun tak bertentangan sedikitpun dengan nilai-nilai agama ${ }^{43}$, utamanya yang mengedepankan ketentraman, kedamaian, keadilan, dan kesejahteraan.

Sebagai bangsa yang mayoritas agama Islamnya tertinggi, warga Indonesia meski sadar akan legalnya keberagaman beragama di dalam Islam itu sendiri. Sebagai agama paripurna Islam merupakan agama representatif dalam menanungi agama-agama yang lain. Islam menjadi contoh agama yang menyejukkan yang bisa harmonis dengan agama-agama lainnya. Dan inilah yang pantas diterapkan oleh masyarakat Indonesia, mengingat bangsa Indonesia terdiri dari berbagai agama-agama, sebagaimana di awal disebutkan.

Harus disadari bahwa berkehidupan di Indonesia bukan seperti berkeheidupan di negerinegeri Timur Tengah yang begitu minim dalam kekuatan menghormati pluralitas agama dan keyakinan $^{44}$. Indonesia adalah negara agama-bangsa, di mana seharusnya keduanya bisa harmonis dalam setiap individu masyarakatnya. Menjunjung tinggi niai-nilai agama, namun tidak mengesampingkan keberagaman- dan saling menghormati satu sama lain. Kesadaran inilah yang akan menghantarkan masyarakat kita di era kini untuk mengembalikan budaya keberagaman- di negeri ini.

\footnotetext{
${ }^{42}$ Mujamil Qomar, Fajar Baru Islam Indonesia, (Bandung: Mizan, 2012), hal. 8

${ }^{43}$ Hamka Haq, Kandungan Nilai-Nilai Islam dalam Pancasila, 207

${ }^{44}$ Said Aqil Siroj, Islam Kebangsaan, (Jakarta: Fatma Press, 1999), hal. 165
} 


\section{Kesimpulan}

Keberagaman merupakan sebuah keniscayaan yang tidak bisa diperdebatkan. Khususnya di bumi nusantara yang merupakan negara yang beragam dalam banyak sisinya, baik keberagaman suku, ras, agama, budaya, dan keberagaman lainnya. Bukan lain, keberagaman memiliki tujuan yang sangat mulia, yaitu menciptakan sikap saling sopan santun dan saling menghormati serta satu sama lain membangun sikap kemaslahatan demi mencapai keberhasilan dalam setiap lini masyarakat. Hal ini sangat selaras dengan misi maqhasid al-syari'ah yang menomorsatukan kemaslahatan bersama.

Keberagaman di negeri ini telah terlahir sejak waktu yang lama dan sungguh sangat selaras dengan nilai-nilai al-Quran, yaitu meniscayakan keberagaman. Al-Quran sebagai sumber hukum awwali melegalkan pluralitas yang telah lama ada di pundak bangsa Indonesia. Sehingga hal ini tidak bisa dinegasikan dan menggantinya untuk menjadi satu dengan meniadakan kebudayaan keragaman tersebut. Budaya keberagaman harus terus dipupuk dan dikembalikan kepada asalnya, yaitu tidak boleh ada gap secuilpun antar perbedaan agama, dan juga keberagaman lainnya. Nilai-nilai sejati dalam wahyu suci al-Quran harus diimplementasikan dengan nyata di Nusantara melalui dikembalikannya budaya kerukunan, khususnya keberagaman agama di negeri ini.

\section{DAFTAR PUSTAKA}

Al-Baidhawi. Anwar At-Tanzil dan Wa Asrar At'takwil, Beirut: Daar Ihya Al-Turats Al-Arabi. 1438.

Al-Barushi, Haki. Tafsir Ruh Al-Bayan, Beirut: Daar Al-Fikr. 1440.

Al-Alushi. Ruh Al-Ma'ani fi Tafsir Al-Quran wa Al-Sab’u Al-Matsani, Beirut: Daar Al-Kutub Al-Islami. 1415.

Al-Shobuni, Muhammad Ali. Shafwa Al-Tafasir Tafsir AL-Quran Al-Karim, Beirut: Daar AlFikr. 1421.

Al-Suyuthi, Imam jalaludin Al-Mahali, Tafsir Jalalain, Bandung: PT Sinar Baru Al-Gensindo. 2012. 
Didah, Indeks Kerukunan Umat Beragama 2016 Naik, http://www.kemenag.go.id Fadhlullah, Husein. Tafsir Min Wahyi Al-Quran, Beirut: Daar Al-Malaak. 1419. Fattah, Agus Salim Fattah. Pesantren Membangun Bangsa, Tangerang: Compass. 2009.

Haq, Hamka. "Kandungan Nilai-Nilai Islam dalam Pancasila", dalam jurnal Millah Vol. XIII, No. 1, Agustus 2013.

Husein Muhammad, Husein. Mengaji Pluralisme, Bandung: Mizan. 2011.

Ibn Athiyah. Muharrar Al-Wajiz, Beirut: Dar Al-kutb Al-Islamy. 1422.

Ibnu Katsir. Tafsir Al-Quran Al- 'Azhim, Beirut: Daar Al-Kitab Al-Islami. 1419.

Ibn Mahmud, Nimatullah. Fawatih Al-Ilahiah wa Al-Mafatih Al-Ghaibiah, Mesir: Daar Rukaab Li An-Nasyr. 1419.

Idrus Ruslan, Ruslan. "Membangun Harmonisasi Kehidupan Berbangsa dan Bernegara dengan Nilai Islam pada Pancasila", dalam Jurnal TAPIs: IAIN Raden Intan Lampung, Vol. 9, No. 2, 2003.

Khoir, Awas! Buku Radikal Pelintir Ayat Al-Quran, NU Online/com/new/, www. nuonline.co.id

Kushardini, Aulia. Kalau Agama Itu Urusan Manusia dan Tuhannya, Kenap Tanya Dia Gak Puasa, www.hipwee.com

Muhammad. Kanzul Al-Daqa’iq wa Bahru Al-Ghara'ib, Tehran: Muassasah Athab'ah wa AlNasyr. 1409.

Naharong, Abdul Musi. “Teologi Kekerasan: Pandangan Jihad Abdul Salam Faraj dan Imam Samudra", dalam jurnal Falsafah dan Agama, vol. 1, No. 1, April 2007.

Qomar, Mujamil. Fajar Baru Islam Indonesia, Bandung: Mizan. 2012. HQosim, Hasan. Pemikiran Fazlur Rohman, www.blosspot.co.id

Rasyid, Rasyid. HTI Gagal Paham Khilafah, Ciputat: Pustaka Compass. 2016.

Saifullah Rohman, Saifullah. "Kandungan Nilai-nilai Islam dalam Pancasila”,dalam Jurnal Millah: Pusat Penelitian Kemasyarakatan dan Kebudayaan (PMB-LIPI), Vol. xiii, No. 1, 2013. 
Shihab, Quraisy. Tafsir Al-Misbah, Jakarta: Lentera Hati. 2002.

Siroj, Said Aqil. Islam Kebangsaan, Jakarta: Fatma Press. 1999.

Suyuthi, Jalaludin. Al-Dura Al-Mansur, Qum: Maktabah Al-Mar'asyi An-Najafi. 1400.

Syaikh, Abdullah Bin Muhamad Bin Abdurrahman Bin Ishaq Alu. Tafsir Ibn Katsir, Jakarta: Pustaka Imam Syafi'i. 2011.

Utsman, Abdul Malik Utsman, "Ismah Rahmah dan Wasathiyah”, dalam jurnal Humanika Vol. 15 Nomor 1. September 2015.

Zuhdi, Nurdin. “HERMENEUTIKA AL-QUR'AN: Tipologi Tafsir Sebagai Solusi dalam Memecahkan Isu-Isu Budaya Lokal Keindonesiaan", dalam jurnal ESENSIA Vol. XIII No. 2 Juli 2012.

Hermeneutika Al-Qur'an: Tipologi Tafsir Sebagai Solusi dalam Memecahkan Isu-Isu Budaya Lokal Keindonesiaan. Yogyakarta: Lkis. 2016. 